\title{
En ny redaktion
}

Museologien er kendetegnet ved at være både en praktisk og teoretisk disciplin. Den udføres især på museerne og tilsvarende kulturarvsinstitutioner, og der undervises og forskes i den, bl.a. på universiteterne og på andre højere videregående uddannelser i hele Norden. Det er meget vigtigt, at alle institutionelle synsvinkler netop derfor blandes i tidsskriftets vifte af artikler. Det har altid været tidsskriftets linje, og det er den nye redaktions intention fortsat at holde fast i den, men det kan vi ikke gøre uden artikelbidrag fra både praktikere og teoretikere indenfor museologien.

Museologien er som disciplin selv bred i al sin mangfoldighed, der spænder over så vidt forskellige, men alle relevante emner: fra museumshistorie, over samlingsforvaltning, formidling og forskning til samfundsmæssige betingelser og rammer for museerne og deres virke. Denne mangfoldighed forsøger vi også med dette nummer at illustrere med forskellige artikler, hvor der stilles spørgsmål, diskuteres, vurderes og kritiseres.

Der er i tidsskriftet fokus på den historiske formidlingsform, der kaldes "levendegørelse" , og den etisk forsvarlige grænse mellem faglig relevant formidling og ønsket om at intensivere publikums oplevelsesdimension. Der er en artikel om behovet for en forøget indsamling af og forskningsmæssig opgradering af den industrielle kulturarv; en anden artikel der argumenterer for en mere kvalitativ formidling af den fysiske kulturarv; en fjerde artikel som udtrykker 
ønske om en større opmærksomhed overfor social inclusion-programmet på især kunstmuseerne; to artikler om Det Kgl Kunstkammer og dets betydning og meget mere. Så glæd jer!

Artiklerne afspejler alle de mange relevante diskussioner, der foregår rundt omkring i de museologiske miljøer, men samtidig vil vi frem over forsøge at være opmærksomme på nye museologiske områder og analytiske discipliner som fx udstillingsanalyse, udstillingskritik, konferencekritik, museologiske litteraturanmeldelser af udstillingskataloger og "genopdagelsen" af museologiske klassikere eller portrættering af vigtige museologiske teoretikere, historikere og praktikere, så den museologiske virkelighed og forskning bliver behørigt udfordret.

Ane Hejlskov Larsen 